\title{
大都市圏郊外部における超小型モビリティの 活用可能性に関する研究
}

\author{
須永 大介 1 -青野 貞康 $2 \cdot$ 松本 $\quad$ 浩和 ${ }^{3} \cdot$ 寺村 泰昭 $4 \cdot$ 久保田 尚 5 \\ 1正会員 一般財団法人計量計画研究所 都市交通研究室（ $=160-0845$ 東京都新宿区市谷本村町2-9) \\ E-mail: dsunaga@ibs.or.jp \\ 2正会員 一般財団法人計量計画研究所 都市交通研究室（ $\overline{1} 160-0845$ 東京都新宿区市谷本村町2-9） \\ E-mail: saono@ibs.or.jp \\ 3正会員 一般財団法人計量計画研究所 都市交通研究室（干160-0845 東京都新宿区市谷本村町2-9) \\ E-mail: hmatsumoto@ibs.or.jp \\ 4非会員 さいたま市 環境局環境未来都市推進課（テ330-9588 埼玉県さいたま市浦和区常盤6丁目4-4） \\ E-mail: eec46-s1h1@city.saitama.lg.jp \\ 5フェロー会員 埼玉大学大学院教授 理工学研究科（†338-8570 埼玉県さいたま市桜区下大久保255) \\ E-mail: hisashi@dp.civil.saitama-u.ac.jp
}

近年, 地域の手軽な足となる 1 人〜 2 人乗り程度でエネルギー消費量が通常の自動車の $1 / 6$ 程度である超 小型モビリティの導入促進に向けた取り組みが全国で展開されている.

本稿では，さいたま市において平成26年度に実施された超小型モビリティの実証実験結果に基づき，大 都市圈郊外部における超小型モビリティの活用可能性について検証を行った．その結果，高齢化が進む市 周辺部の住宅団地においては, 高齢者による買い物や通院等の短距離移動を中心に超小型モビリティが活 用される可能性があること, 都心部においては, 超小型モビリティを用いたワンウェイ型カーシェアリン グを導入した際に, 平休日ともに都心部内移動において活用される可能性があることを明らかにした.

Key Words : micro electric vehicle, adaptability, car sharing, suburb, metropolitan

\section{1. はじめに}

近年，世界各国において地球温暖化防止に向けた取り 組从が行われてきている，我が国においても $\mathrm{CO}_{2}$ 排出量 削減に向けた取り組みが推進され，運輸部門においても $\mathrm{CO}_{2}$ 排出量の削減が求められている.

また，我が国においては，モータリゼーションの進展 に伴う公共交通利用者の減少によって，地方部だけでな く大都市圈においても公共交通のサービスレベルが低下 する地域が増えてきている．今後予想される高齢化の進 展を考えると, 自動車を運転することができない高齢者 が増加することが想定され，今後に向けて，地域の移動 の足を確保することが重要である.

超小型モビリティは, 自動車よりコンパクトで, 地域 の手軽な移動の足となる 1 人 2人乗り程度の車と定義さ れ，エネルギー消費量は，通常の自動車に比べ $1 / 6$ 程度 である ${ }^{1)}$ ここの長所を生かし，省エネ・低炭素化への寄 与や子育て世代・高齢者の移動支援を実現することが期
待されている. 国土交通省では, 超小型モビリティの普 及や関連制度の検討に向けて, 成功事例の創出, 国民理 解の醸成を促寸観点から, 平成25年1月に超小型モビリ ティの公道走行を可能とする認定制度, および先導・試 行導入の取り組みを支援する補助制度を創設しており， 超小型モビリティの導入促進に向けた取り組みが全国で 推進されている状況にある.

これまでのところ, 超小型モビリティを含むパーソナ ルモビリティに関する既往研究としては, 混合交通の中 での車両の共存可能性，新しい車両としての受容性，車 両の導入が環境や生活に与える影響等が挙げられる.

混合交通の中での車両の共存可能性として，金・高 崎は，超小型モビリティを含むコンパクト交通手段を 対象に，道路交通における次世代コンパクト交通手段の 共存性について特性把握を行った。その結果として, 現 在の道路空間はコンパクト交通手段を有効に利用できる 交通環境ではなく普及にあたっては慎重な検討が必要と している. 
また，新しい車両としての受容性に着目した研究とし て，李ら ${ }^{3)}$ は豊田市における立ち乗り型パーソナルモビ リティ・ビークルの実証実験結果から車両の利用意向と 受容性・意識構造について分析を行い，適合性の高い意 識構造モデルを構築した。 また，中村ら ${ }^{4}$ は熊本市にお ける超小型モビリティを用いたワンウェイ型シェアリン グシステムの導入可能性についてシミュレーションプロ グラムを開発して分析を行い，各種条件の中で料金設定 の影響が大きいことを明らかにしている.

車両の導入が環境や生活に与える影響に着目した研究 として，須田ら ${ }^{5}$ は三大都市圈への自転車モードと並行 二輪車モードのハイブリッド方式パーソナルモビリティ ・ビークルの導入による $\mathrm{CO}_{2}$ 削減効果と高齢社会への順 応性を検証，短距離移動や，ある程度距離のある移動の フィーダ部分，施設内の移動のそれぞれにおいて高齢者 の移動支援ツールとしての期待を示した．石橋らのは利 用状況と意識調査からパーソナルモビリティのうち自転 車やバイク, 自動車の価值構造の把握を行い, 身軽さや 気軽さが長所として選ばれていることを明らかにした。 溝上ら`は高齢者・障害者が高いQOLを維持するための パーソナルモビリティの一つである電動車いすの活用法 を検証し，利用頻度が高い被験者ほど生活活動範囲が広 がること等を示した。落合ら ${ }^{8}$ はEV利用を含む交通行動 まで対象にした市区町村の電力自給自足の可能性につい て分析を行い, 自動車保有率が高くEVの普及率が見込 める市区町村では自給率が高くなることを明らかにした. また，海外においても，Vishwanathら ${ }^{91}$ はZipcarやCar2Go， GoGet, Flexicar等のカーシェアリングサービスの普及状 況を踏まえ, パーソナルな交通と公共交通の中間的なサ ービスであるPersonalised Public Transportation Serviceを提唱 している. その中では，環境面での貢献や車両サイズの 小ささによる走行空間や駐車空間の節約等が期待される ことから, サービス内に超小型モビリティを組み込むこ とをキーポイントの一つに挙げている.

パーソナルモビリティに関する既往研究では, 立ち乗 り型パーソナルモビリティや車いす等の既存車両に関し ては実際の利用を通じた検証が行われている。 これに対 し4輪EVである超小型モビリティについては，理念的な 検討やシミュレーションを用いた仮想的な検討に留まり， 実際の市民利用を通じて利用特性や利用意向等を取得デ 一タに基づき実証的に明らかにした事例は存在しない.

これに対し本研究では，さいたま市で実施された超小 型モビリティの実証実験結果に基づき, 超小型モビリテ イの活用可能性について明らかにすることを目的とする. 本研究の構成は以下の通りである.まず, さいたま市の 特性と超小型モビリティ実証実験の概況について整理す

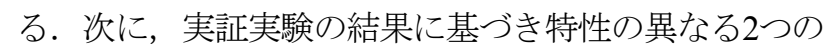
地区における利用実態と意向，評価を明らかにする．最
後に, 大都市圈郊外部における超小型モビリティの活用 可能性について論じる.

\section{2. さいたま市実証実験の概況}

\section{（1）さいたま市の特性}

さいたま市内の人口分布をみると，鉄道軸沿線上の人 口密度が高くなっている. 一方で, 鉄道駅から離れた地 域においても 2,000 人 $/ \mathrm{km}^{2}$ を超える地域がある等，多くの 人が居住している状況にある. 市の総人口に対する高齢 者の割合は現状では全国平均よりも低いが，今後高齢者 の増加が見込まれ，2050年には35\%を超えるものと推計 されている. また，市内の高齢化率は，鉄道駅から離れ た人口密度が相対的に低い地域において高くなっている。

さいたま市の公共交通網は，南北方向は鉄道，東西方 向は鉄道および路線バスにて形成されているが，市内に は交通空白・不便地区が存在する (図-1).

さいたま市の発生集中交通量における交通手段構成比 は，自動車が全体の $28 \%$ を占め最も多く，過去 10 年では 減少しているものの鉄道や自転車を上回っている.さら に, 自動車の分担率は鉄道駅から離れた地域で高くなる 傾向を有する.

つまり，さいたま市においては，公共交通サービスが 相対的に低い水準にある地域において自動車に依存, 一 方でこれらの地域を中心に先行的に高齢化が進展してい ることから，高齢者をはじめとした自動車を運転できな い居住者に移動の問題が生じつつあると考えられる。

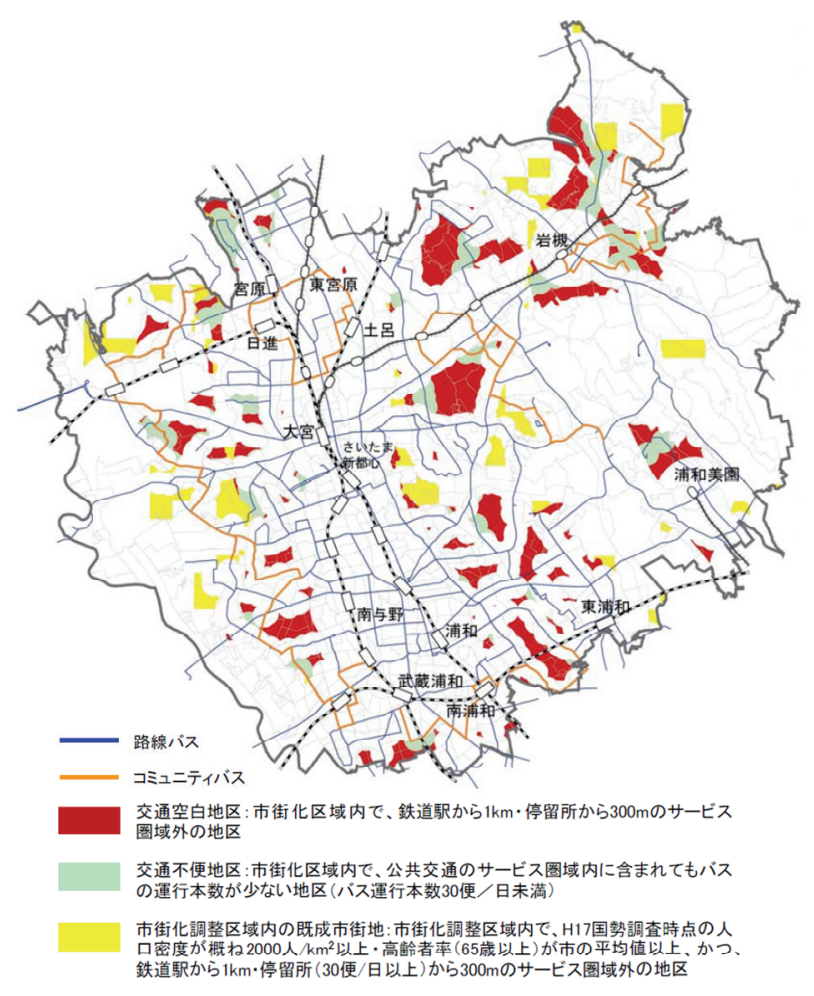

図-1さいたま市における交通空白・不便地区 ${ }^{10)}$ 
表-1 平成26年度実証実験の概要

\begin{tabular}{|c|c|c|c|c|}
\hline 対象 & 実験名称 & 概要 & 利用者数 & 貸出期間 \\
\hline \multirow{8}{*}{ 個人 } & 一般利用モニター（MROC） & $\begin{array}{l}\text { 試乗者グループとの定期的な意見交換やワークショップを通 } \\
\text { し, 車両の活用方法を検証 }\end{array}$ & 24人 & 1回 \\
\hline & 新規免許取得者等モニター & 教習所内での試乗会を実施し, 運転に不慣れな層の需要を検証 & 60人 & 1回 \\
\hline & 一般利用モニター（QOL） & $\begin{array}{l}\text { 家庭に車両を貸出し日常生活で使用させることで, 生活の質 } \\
\text { (Quality OfLife) に与える影響を検証 }\end{array}$ & 24人 & 2週間 \\
\hline & 市民市内探検 & \multirow{4}{*}{$\begin{array}{l}\text { 車両を1日貸出し，市民やホテル宿泊者の市内回遊やプール利 } \\
\text { 用・岩槻ねぎ掘り体験への移動に使用させることで, 観光目的 } \\
\text { での親和性を検証 }\end{array}$} & 43組78人 & 1日 \\
\hline & ホテル宿泊者市内探検 & & 1人 & 1日 \\
\hline & プール利用 & & 7組14人 & 1日 \\
\hline & 岩槻ねぎ掘り & & 12組23人 & 1日 \\
\hline & $\begin{array}{c}\text { ワンウェイ型カーシェアリン } \\
\text { グ【都心部実証実験】 }\end{array}$ & $\begin{array}{l}\text { 有償ワンウェイ型カーシェアリングシステムを実施し, 公共交 } \\
\text { 通を補完する交通システムの可能性を検証 }\end{array}$ & $\begin{array}{l}\text { 447人 } \\
\text { (会員数) }\end{array}$ & 2か月 \\
\hline 企業 & 営業車等モニター & $\begin{array}{l}\text { 企業に車両を貸出し, 日常の移動に使用させることで, 企業活 } \\
\text { 動への親和性を検証 }\end{array}$ & $\begin{array}{c}\text { 94人 } \\
\text { 11事業者 }\end{array}$ & 2週間 \\
\hline 自治会 & $\begin{array}{l}\text { 自治会モニター } \\
\text { 【交通不便地区実証実験】 }\end{array}$ & $\begin{array}{l}\text { 自治会に車両を貸出し, 自治会管理の下で運用させることで, } \\
\text { 交通不便地区での親和性を検証 }\end{array}$ & \begin{tabular}{c|} 
33人 \\
(講習参加) \\
\end{tabular} & 2週間 \\
\hline
\end{tabular}

\section{（2）実証実験の全体構成}

さいたま市においては，高齢者等の移動支援，および 交通の低炭素化を目的として，平成25年度に「さいたま 市小型電動モビリティ利活用推進協議会(構成主体 :さ いたま市，本田技研工業株式会社，株式会社本田技術研 究所)」を設立し，国土交通省の認定制度・補助制度を 活用して，超小型モビリティの導入促進に向けた実証実 験を行っている．平成26年度は，表-1に示す実証実験を 行った．実証実験にあたっては，Honda製の「MC- $\beta 」 を$ 用いている．車両の概要を表-2に示寸.

\section{3. 実証実験結果に基づく利用実態と意向の分析}

\section{（1）超小型モビリティに期待される役割}

さいたま市内では特に周辺部において多くの交通空 白・不便地区が存在している．また，都心部に着目する と，大宮駅周辺には各種施設が広範に分布し，鉄道やバ スで大宮駅に到達した後の移動負担が大きいと推察され る。つまり，さいたま市では公共交通網が発達している が，公共交通端末での移動について問題があると考える.

これに対し，超小型モビリティは通常の自動車と比べ, 1)小型で運転や駐車がしやすい，2)最高航続走行距離が 短い特徴を有する。これらの特性を踏まえると，同時に 移動する人員が少なく比較的短距離であるという条件を 満たす移動場面において活用が期待できると推察する.

以下では，上記の条件を満たす移動について「交通不 便地区」「都心部」の特性の異なる2つの地区における 超小型モビリティの利用実態について分析を行う.

\section{（2）交通不便地区における利用実態と意向}

さいたま市の交通不便地区の一つである岩槻区河合地 区では，地域が過去からコミュニティバスの運行導入を
表-2 実証実験使用車両の概要

\begin{tabular}{|l||l|}
\hline 名称 & MC- $\beta$ \\
\hline メーカ一 & Honda \\
\hline 定員 & 2名 \\
\hline 最高速度 & $70 \mathrm{~km} / \mathrm{h}$ 以上 \\
\hline 最高航続走行距離 & $80 \mathrm{~km}$ 程度 \\
\hline 充電時間 & 3時間以下 $(200 \mathrm{~V}) / 7$ 時間以下 $(100 \mathrm{~V})$ \\
\hline モ一タ一出カ & 定格 $6 \mathrm{~kW} /$ 最大 $11 \mathrm{~kW}$ \\
\hline サイズ(全長/全幅/全高) & $2,495 / 1,280 / 1,545(\mathrm{~mm})$ \\
\hline
\end{tabular}

表-3 交通不便地区実証実験の概要

\begin{tabular}{|c|c|}
\hline 地区 & |さいたま市岩槻区河合地区 \\
\hline 実施時期 & \begin{tabular}{|l} 
第1回: 平成26年9月8日(月) 21日(日) \\
第2回: 平成26年12月6日(土) 21日(日)
\end{tabular} \\
\hline 試乗会参加者数 & \begin{tabular}{|l} 
第1回: 21 名 \\
第2回: 17 名
\end{tabular} \\
\hline 利用者数 / 利用回数 & \begin{tabular}{||l|} 
第1回: 7名 $/ 12$ 回 \\
第2回: 17 名 $/ 39$ 回
\end{tabular} \\
\hline 車両 & $M C-\beta \quad 2$ 台 \\
\hline 貸出方法 & \begin{tabular}{|l|l} 
第1回: 担当班長に電話予約, 鍵借受 \\
第2回: 台帳記載で予約, カードキ一利用
\end{tabular} \\
\hline 車両改良内容(第2回) & ウインドシールドとカードキ一装着 \\
\hline
\end{tabular}

希望していたが，現在のところ導入検討が開始されてい ない状況にある。この河合地区を対象として，実証実験 結果に基づき，交通不便地区における超小型モビリティ の利用実態と意向に関する分析を行う.

\section{a) 実証実験の概要}

交通不便地区の実証実験は地元の東海自治会(205世帯) の協力を得て，2回に分けて実施した.

実証実験の概要を表-3に示す。実証実験においては, まず東海自治会内居住者全世帯を対象に，回覧板に同封 する形で試乗会の案内チラシを各戸に配布，試乗会参加 者を募った。この試乗会に参加し車両利用方法の講習を 受けた住民が，実証実験期間中を通じ地域内の東海自治 会館に配置した2台の車両を自由に利用できるものとし た. 参加者は案内チラシを見て超小型モビリティに興味 を持った者であることから，選択バイアスが生じている 
可能性があり, 以降の結果の解釈には留意が必要である. また，実証実験の事前，及び各回の実証実験後に，それ ぞれアンケート調查を行っている. アンケート調査の概 要を表-4に示す．第1回では貸出方法や車両装備につい て満足度が低かったため，第2回では改良を図っている。 結果として，第1回では利用回数が12回であったが，第2 回では39回に増加したことから，利用しや寸い貸出形態 への改良が実現できたものと考える. 更に, 利用者への ヒアリング調査からは，利用者が自治会内の住民に対し てロコミでの利用促進PRを行ったことが把握され，こ のことも利用回数増加の一因であると推察される.

\section{b) 地域の特性}

対象地域は, さいたま市北東部に位置し, 最寄りの駅 までの距離は $2 \mathrm{~km}$ 程度, 最寄りバス停までの距離が $500 \mathrm{~m}$ 以上あり, かつバスの運行本数も1時間に1本程度と, さ いたま市内の他地域と比較して少ない状況にある(図-2).

\section{c）超小型モビリティの利用状況と意向}

以下では，実証実験の利用実績データと事前・試乗会 時・事後に実施したアンケートに基づき，利用状況と評 価を明らかにする。

地域の居住者と実証実験での利用者の年齢階層を図-3 に示す。対象地域は昭和50年代に開発された住宅団地で あり，国勢調査による高齢化率は $23.1 \%(\mathrm{H} 22)$ と市平均を 上回る. 全戸に配布した事前アンケート回答者の過半数 が65歳以上であることから，高齢者からの回答が多く寄 せられた．また，実証実験に先立つ試乗会に参加した対 象者の中で高齢者が占める割合は各回とも70\%を超えた。 このことから，対象地域ではさいたま市の平均より高 齢化率が高いこと，居住者の年代構成と比較して相対的 に高齢者からの回答が多く得られていることが明らかと なった. この理由としては, 自治会長が中心となり地域 への周知活動を展開したため, 人的なつながりの強い層 が多く試乗会に参加したからであると推察される。また, 男女比については，男性の方が多い，対象地域の自家用 車保有比率としては，事前アンケート回答者の $53 \%$ \%゙自 分専用の自動車を，24\%が家族共用の自動車をそれぞれ 有すると回答しており, 合わせて $78 \%$ 分自動車を保有し ており, 高い保有水準にあることが把握された。

事前調查における，日頃の移動で困っている点の回答 状況を図-4に示す，これより，対象地域では，「バスの 利用のしにくさ」を問題と感じる人が44\%を占め, 次い で「自動車運転中における他車との寸れ違い時の恐怖 感」が26\%を占めることから，公共交通の利便性や運転 時の安全への不安等が問題として認識されていることが 明らかとなった．また，事前調査では自動車を運転でき ない層からも回答が寄せられており, 対象地域の居住者 の中で外出への負担を感じている層が $10 \%$ 以上存在する 実態が明らかとなった.
表-4 交通不便地区実証実験におけるアンケート調査の概要

\begin{tabular}{|c|c|c|c|}
\hline & \multirow{2}{*}{ 事前アンケート } & \multicolumn{2}{|c|}{ 事後アンケート } \\
\hline & & 第1回 & 第2回 \\
\hline 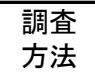 & \begin{tabular}{|l} 
回覧板同封にて配布, \\
郵送回収
\end{tabular} & \multicolumn{2}{|c|}{ 郵送配布回収 } \\
\hline 配布数 & \begin{tabular}{|l} 
410票 ※全205世帯 \\
に1世帯当たり2枚
\end{tabular} & $\begin{array}{c}\text { 33票 } \\
\text { (試乗会参加者) }\end{array}$ & $\begin{array}{c}19 \text { 票 } \\
\text { (試乗会参加者) }\end{array}$ \\
\hline 回収数 & 140票 & 21票 & 17票 \\
\hline 回収率 & $34.1 \%$ & $63.6 \%$ & $89.5 \%$ \\
\hline
\end{tabular}

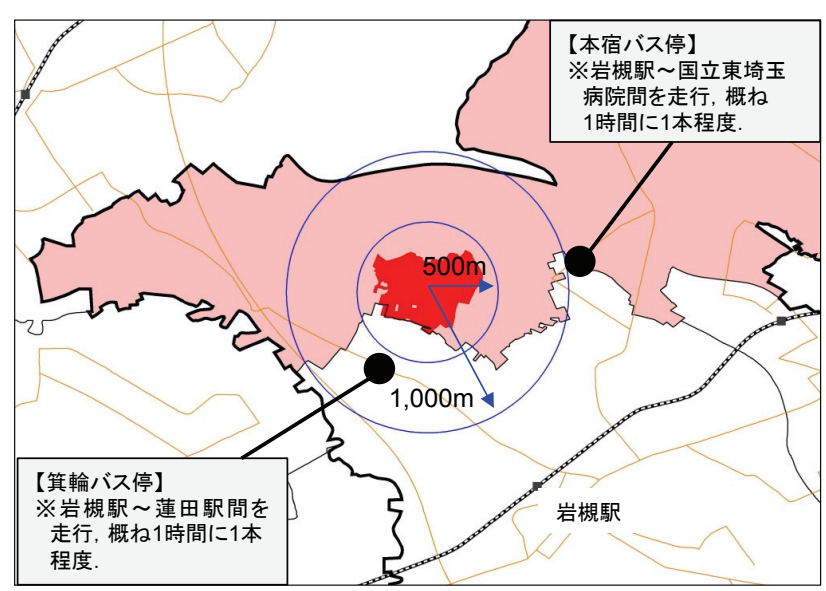

図-2 交通不便地区実証実験対象地域の位置

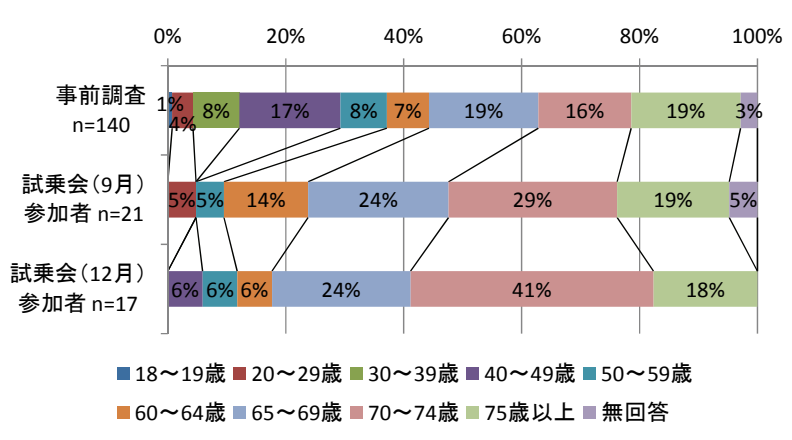

図-3 居住者と試乗会参加者の年齢構成

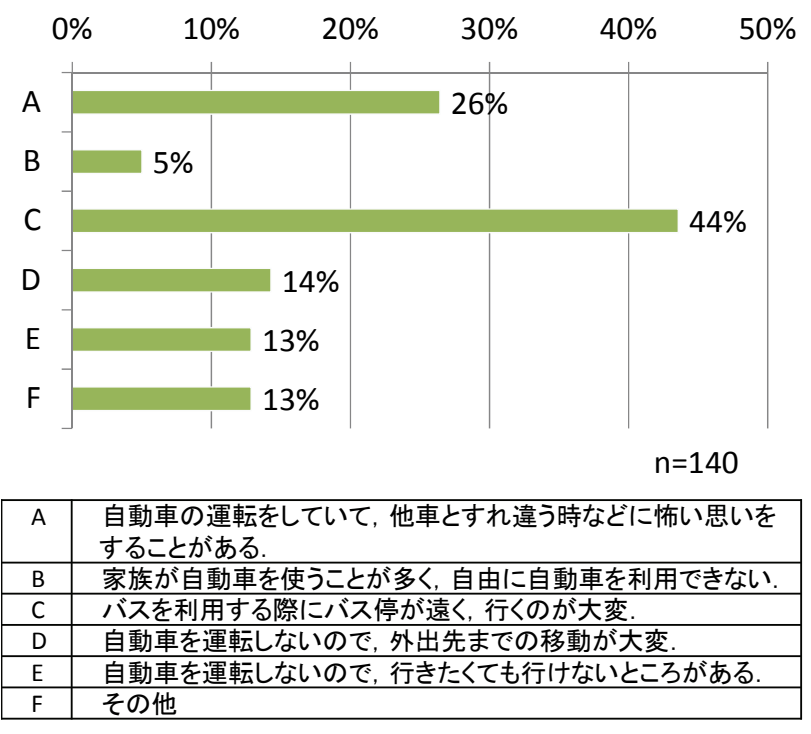

図-4 日頃の移動で困っている点 
さらに，実証実験期間中の各日における利用回数を図 -5に，平休別の1日あたり利用回数と1回あたり走行距離 を表-5に示す。この結果から，今回の実証実験では，ほ ぼ毎日1回以上の利用がされたこと，土曜・日曜の利用 が相対的に多かったこと，利用1回あたりの走行距離は $20 \mathrm{~km}$ 以下が多く, 主に片道 $10 \mathrm{~km}$ 以内の短距離移動にお いて利用されたことが明らかとなった。

次に，第2回実証実験の事後アンケート結果から，今 回の実証実験における超小型モビリティ利用目的構成を 図-6に示す。これより，今回の実証実験においては，

「体験試乗」として利用された割合が47\%を占め，次い で「買い物」「通院」「送迎」が多くなっている.つま り，新しい乗り物への興味から，体験的な利用が多くな されたこと，それに加え，「買い物」や「通院」等，地 域に多く居住する高齢者の日常の移動場面として想定さ れる移動目的で，多くの利用がなされたことが明らかと なった.

希望する超小型モビリティの保有形態について, 事前 調査に基づく回答結果を図-7に示す，対象地域では，自 動車の保有水準が高い状況にあるが，超小型モビリティ を利用したい意向を有する対象者(全回答者の $52 \%$ )の多 くが希望するのは「地域全体で共有」「今保有する自動

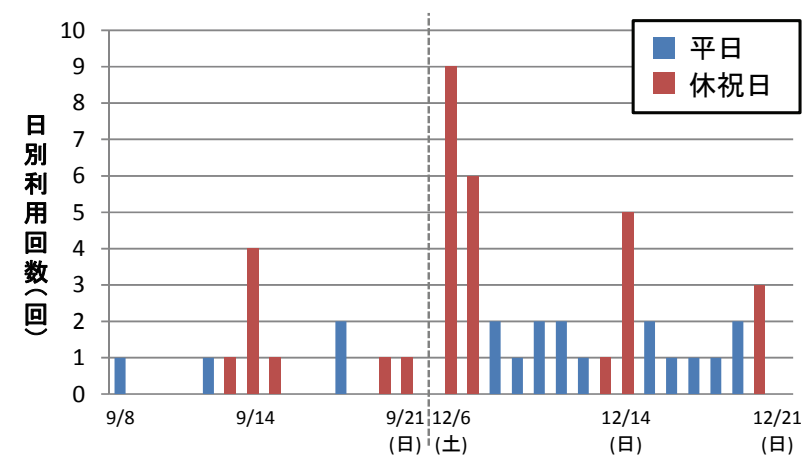

図-5 期間中の日別利用回数(交通不便地区実証実験)

表-5 平休別の1日あたり利用回数と1回あたり走行距離 （交通不便地区実証実験）

\begin{tabular}{|c|c|c|c|c|}
\hline & \multicolumn{2}{|c|}{ 平日 } & \multicolumn{2}{c|}{ 休日 } \\
\cline { 2 - 5 } & $\begin{array}{c}\text { 利用回数 } \\
\text { (回/日) }\end{array}$ & $\begin{array}{c}\text { 走行距離 } \\
\text { (km/回) }\end{array}$ & $\begin{array}{c}\text { 利用回数 } \\
\text { (回/日) }\end{array}$ & $\begin{array}{c}\text { 走行距離 } \\
\text { (km/回) }\end{array}$ \\
\hline \hline 9月 & 0.44 & 22.5 & 1.60 & 17.5 \\
\hline 12月 & 1.50 & 16.5 & 4.00 & 8.4 \\
\hline
\end{tabular}

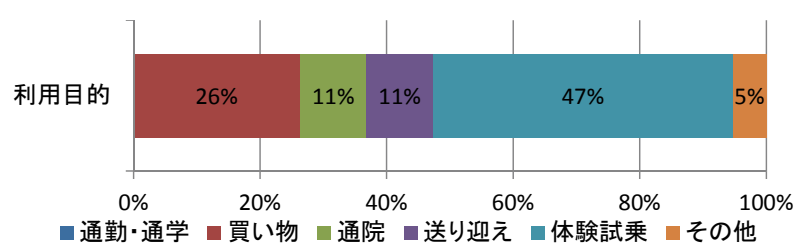

図-6 超小型モビリティの利用目的
車に追加して保有」である，つまり，車両定員が少なく 航続走行距離が短い超小型モビリティを利用するにあた り，現在保有する車両を完全に置き換えることに対して は抵抗感があり, 現在の車両に追加する形で利用するこ とが望まれていること，追加する際には個人保有に加え， 地域での保有も望まれていることが明らかとなった。

d) 超小型モビリティの乗り物としての評価

以下では，第1回実証実験事後アンケート結果から， ガソリンを使わない乗り物としての評価結果を図-8に, 車体の小さな乗り物としての評価結果を図-9に示す.

ガソリンを使わない乗り物の観点からのガソリン車と の比較では，「環境に優しい」に対し肯定的な回答をし た人が9割を超え最も高い評価を得た．次に，「給油不 要で便利」，「音が静か」に対して肯定的な評価が高く なっている. 一方，「充電が心配」と思う人は7割を超 えており, 不安要因となっている.このことから, 特に 環境面や利便性等の点で高い評価を得たものの, 充電に 対して不慣れであることや現在の充電環境に起因して, 充電に対し不安を感じる状況にあったことが理解できる.
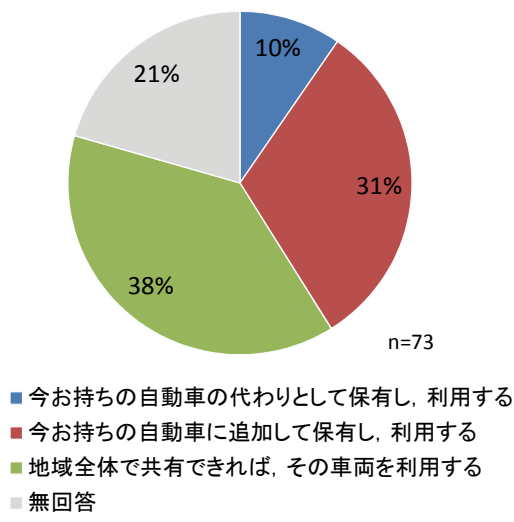

図-7 希望する保有形態

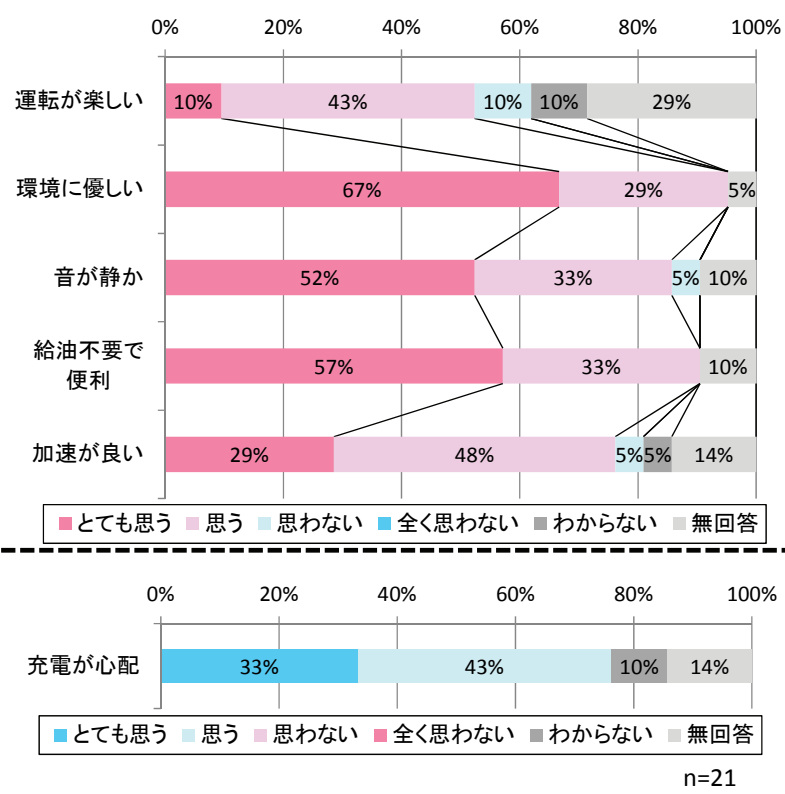

図-8ガソリンを使わない乗り物としての評価 (交通不便地区実証実験) 


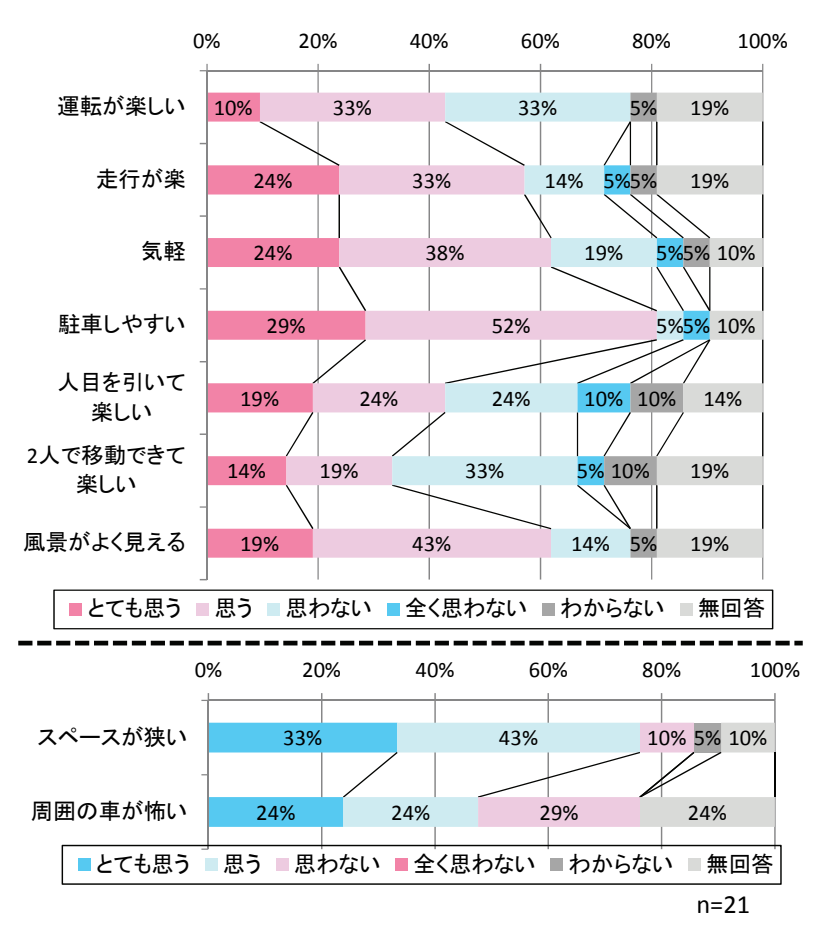

図-9車体の小さい乗り物としての評価 （交通不便地区実証実験）

車体の小さな乗り物の観点からのガソリン車との比較 では，「駐車しや寸い」に対し肯定的な評価をした人が 8割を超え最も高い評価を得た。次に，「気軽」，「風 景がよく見える」，「走行が楽」の評価が高かった。 そ の一方，「スペースが狭い」は7割超が否定的な評価を している. つまり, 駐車の場面で小さな乗り物としての メリットを強く感じ, 走行時にも快適性を感じる一方, スペースの狭さを感じる場面もあったものと考えられる。

\section{（3）都心部における利用実態と意向}

以下では，さいたま市の都心部である大宮駅周辺を対 象とした実証実験結果に基づき，都心部において超小型 モビリティの利用実態と意向に関する分析を行う.

\section{a) 実証実験の概要}

大宮駅周辺では，「低炭素化」，「少子高齢化対策」， 「渋滞解消」に対応した過度に自動車に依存しない交通 社会の実現に向け，公共交通を補完する超小型モビリテ イを活用したカーシェアリングの可能性検証を目的とし て実証実験を行った。実証実験の概要を表-6に示す．実 証実験では大宮駅周辺のエリアに34カ所43車室のステー ションを設置, 営業時間中に9台の車両を配置し, 発着 ステーションが異なるワンウェイ利用が可能なカーシェ アリングのサービスを提供した. 大宮駅周辺のステーシ ョン配置状況を図-10に示寸．なお，ステーションへの 車両配置は，例えば朝は駅から目的地一の利用を想定し て駅周辺に配置するなど, 朝尽夕の 3 時間帯における利 用目的を想定し, 利用が期待されるステーションへ配置
表-6 都心部実証実験の概要

\begin{tabular}{|l|l|}
\hline 地区 & 大宮駅を中心としたエリア \\
\hline 実施時期 & 平成26年10月1日(水) 11月30日(日) \\
\hline 棠業時間 & $9: 00 \sim 20: 00$ \\
\hline ステーション数 $/$ 車室数 & 34 カ所 $/ 43$ 車室(10/28より44車室に増) \\
\hline 講習会参加者数 & 375 名 \\
\hline 利用者数 $/$ 利用回数 & 246 名 $/ 591$ 回 \\
\hline 車両 & MC- $\beta$ 9台 \\
\hline 貸出方法 & スマホやPCを通じインターネット経由で予約 \\
\hline 料金 & $\begin{array}{l}\text { 初乗り10分100円(以後5分100円 }) \\
\text { ※11/22以降は30分無料 }\end{array}$ \\
\hline
\end{tabular}

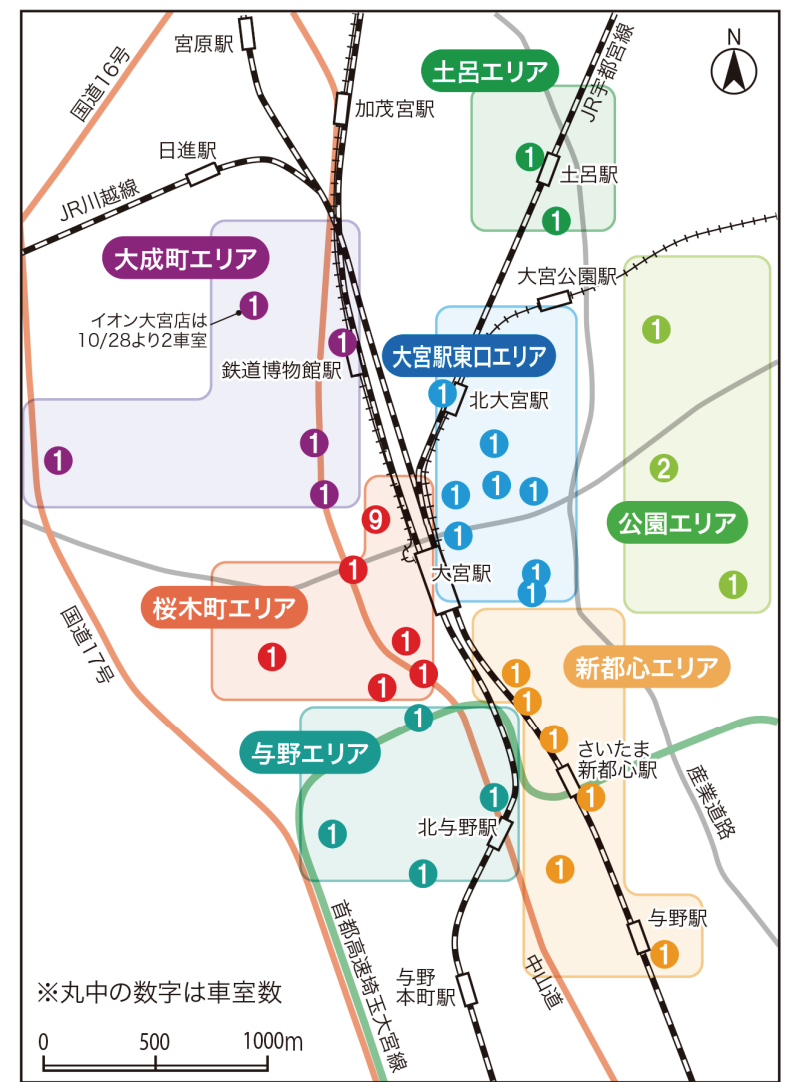

図-10 ステーション配置状況

を行った．さらに，利用の少ないステーションに返却さ れた車両は, 返却から2時間利用が無い場合に, 利用の 見込まれるステーションに再配車を行っており，限られ た車室，車両であっても多くの利用がなされるように配 慮を行った．また，期間中に利用状況を把握し，配置の 見直しを行っている. 営業時間外については全て桜木駐 車場に回送し，充電及び保管を行った.

カーシェアリングの利用にあたっては，事前に1時間 程度の講習会を受講することを義務付け, 講習会終了後 に講習会修了証を発行した。2汃月間を通じ，延べ246名， 591回の利用があった.

\section{b) 地域の特性}

大宮駅周辺には商業・業務施設が広範に立地し, 駅か ら離れると住宅地が分布する．また，大宮駅の東西とも， $2 \mathrm{~km}$ 程度離れた場所に大規模な公園が立地している.

大宮駅周辺の交通状況についてみると, 南北方向に 鉄道が延びている．また，大宮駅に向かって東西方向か 
ら路線バスが集中し，バス交通の軸を形成している．大 宮駅周辺ではさらにさいたま市コミュニティサイクルが ポート数20力所の規模でサービス提供されている.

\section{c) 超小型モビリティの利用実態と意向}

以下では，カーシェアリングの利用実績データと，実 証実験中に実施したアンケート調査結果に基づき，利用 実態と意向を明らかにする.

まず，実証実験での利用者の年齢階層を図-11に示す. 利用者は 40 歳代が $40 \%$ と最も多く, 次いで30歳代が $28 \%$, 50歳代が19\%であった。つまり，交通不便地区の実証実 験と異なり，相対的に若い世代の利用者が多いものと理 解できる. また, 男女比で見ると, 男性が $91 \%$ と圧倒的 多数であった. この要因として, 乗車人員は身長 $135 \mathrm{~cm}$ 以上であることが条件とされ，乳幼児や小学校低学年の 児童を同伴する際の利用が難しいこと，不慣れな車両一 の抵抗感等が推察されるが，今回の実証実験内容は子育 て世代を中心とした女性にとって利用上制約があった恐 れがある。

実証実験期間中の各日における利用回数を図-12に，1 日当たり利用回数と利用1回あたりの走行距離を表-7に, 平休別の利用時間構成比を図-13に示寸. 図-12からは, 今回の実証実験では1日平均で10回程度の利用があった こと, 土日に利用回数が増える傾向にあったこと等が,

表-7からは利用1回あたりの走行距離は $5 \mathrm{~km}$ を少し超える
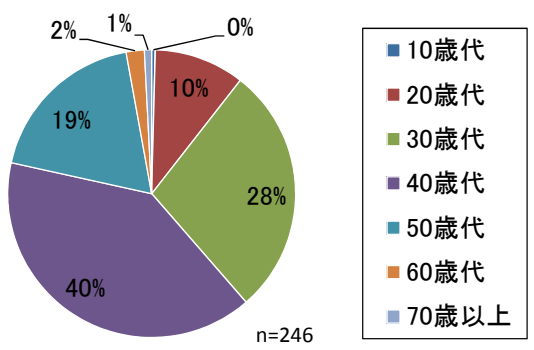

図-11 利用者の年齢階層
程度であり, 交通不便地区よりも短い水準となっている こと，図-13からは平日の $75 \%$ ，休日は $66 \%$ が利用時間 30分未満となっていることがそれぞれ理解できる.

なお，中間web調査においてカーシェアを利用できな かった経験とその原因について把握した結果からは, 利 用しようとしたができなかった経験があったと全87名中 42名が回答し，その原因として約8割が「借りたいと思 ったステーションに車両が無かった」ためと回答した. このことから，車両数の制約によって利用を断念した層 が一定割合存在したことが理解できる.

また，カーシェアリングの利用形態として， ワンウェ イ利用と同一ステーションで発着するラウンド利用の距 離構成比を図-14に示寸. 図-14からは, ワンウェイ利用

表-7 平休別の1日あたり利用回数と1回あたり走行距離 (都心部実証実験)

\begin{tabular}{|c|c|c|c|c|c|}
\hline & \multicolumn{2}{|c|}{ 平日平均 } & \multicolumn{2}{|c|}{ 休日平均 } \\
\hline & & $\begin{array}{c}\text { 利用回数 } \\
\text { (回/日) }\end{array}$ & $\begin{array}{c}\text { 走行距離 } \\
(\mathrm{km} / \text { 回 })\end{array}$ & $\begin{array}{c}\text { 利用回数 } \\
\text { (回/日) }\end{array}$ & $\begin{array}{c}\text { 走行距離 } \\
(\mathrm{km} / \text { 回 })\end{array}$ \\
\hline \multirow{3}{*}{ 10月 } & 前期 & $\begin{array}{l}5.88 \\
\end{array}$ & 3.67 & 15.00 & 6.76 \\
\hline & 中期 & 5.40 & 5.19 & 12.40 & 6.85 \\
\hline & 後期 & 4.11 & 7.18 & 16.00 & 5.52 \\
\hline \multirow{3}{*}{ 11月 } & 前期 & 4.20 & 4.04 & 10.80 & 6.39 \\
\hline & 中期 & 6.67 & 4.44 & 9.50 & 8.20 \\
\hline & 後期 & 17.00 & 4.75 & 26.80 & 5.67 \\
\hline
\end{tabular}

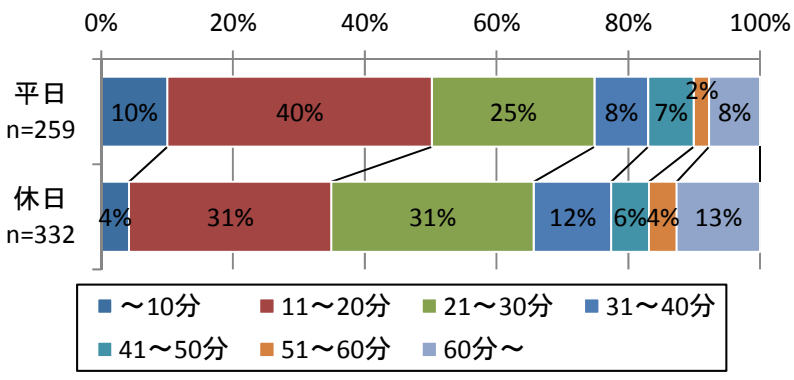

図-13 利用時間の構成比(平日・休日)

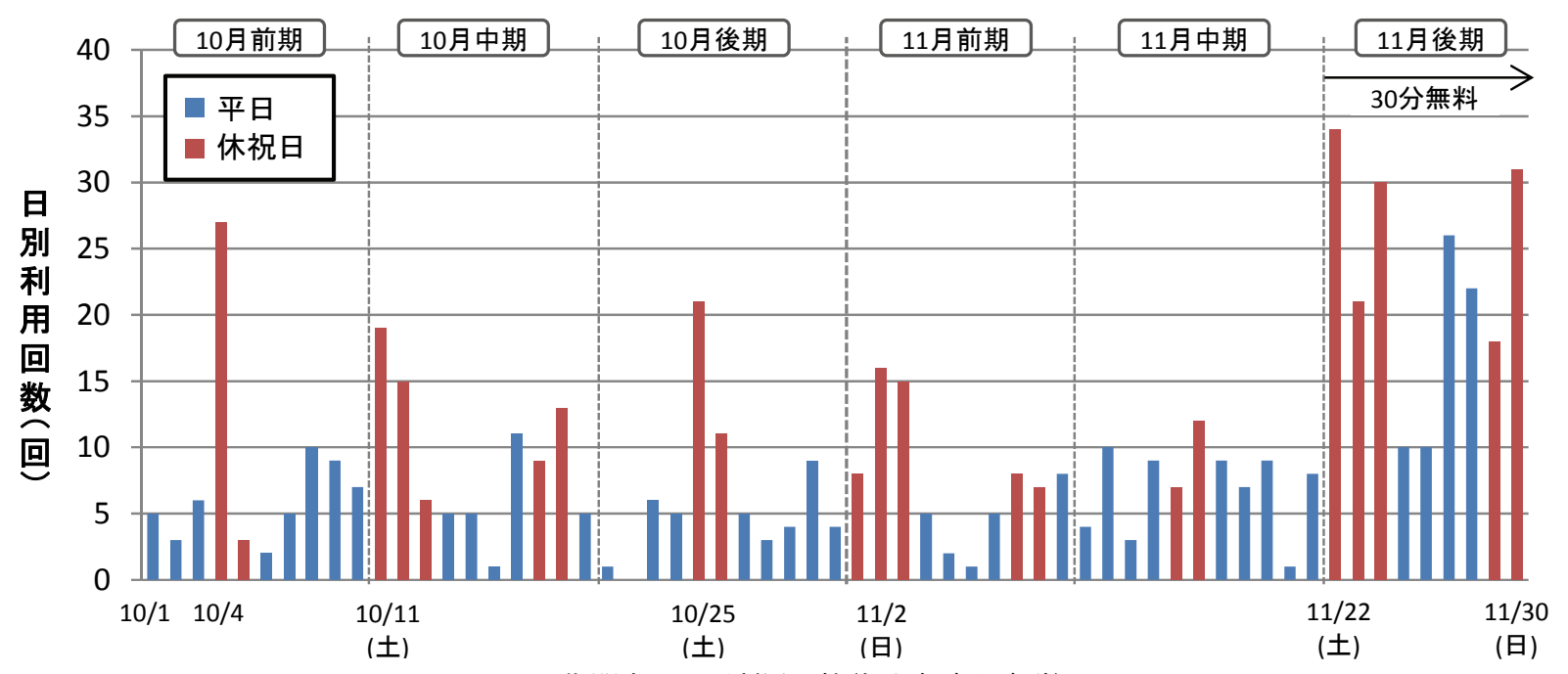

図-12 期間中の日別利用回数(都心部実証実験) 
が 7 割近くに達すること, ワンウェイ型の走行距離の平 均は $5 \mathrm{~km}$ 程度であることが明らかとなった。これらか ら，多くの利用者がワンウェイ利用を選択しており，目 的地の分布に加えて利用形態もその一因として 1 回あた りの走行距離が短くなっているものと理解できる.

利用実態に基づく平休貸出時間帯と利用目的の関係を 図-15に示寸，平日の利用目的は買い物，通勤，観光・ ドライブが，休日の利用目的は買い物，観光・ドライブ がそれぞれ多いことが明らかになった，また，時間帯別 には，平日の午前中はビジネス利用が多く，午後の時間 は買い物，18時以降は通勤(帰宅)が多くなっている状況 が整理された。これらより, 実証実験では時間帯別の移 動ニーズに対してそれぞれの場面で合致し，利用につな がっているものと理解できる，一方で，今回は朝9時以 前のサービス提供がされておらず，帰宅時には利用され ているものの通勤時の需要がとりこめておらず，利用促 進に向けては改善の余地があると考える.

利用実績に基づく利用が多かったステーションと事後 web調査に基づくステーションの設置希望意向を図-16に 示寸．実証実験結果からは，車両基地であり，大宮駅付

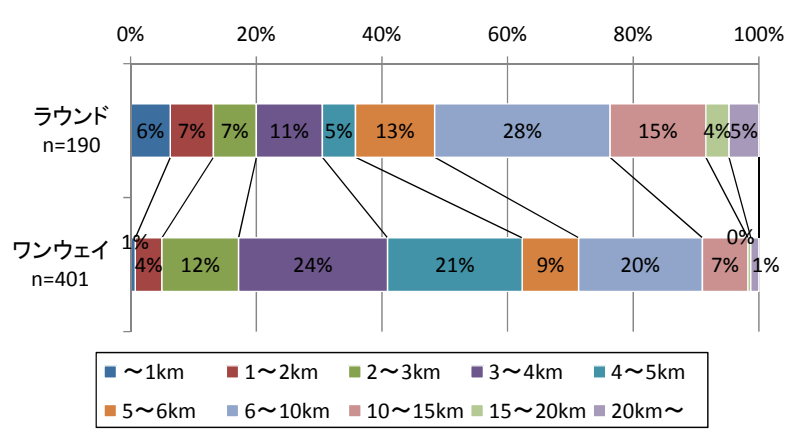

図-14 利用形態別の利用距離構成比

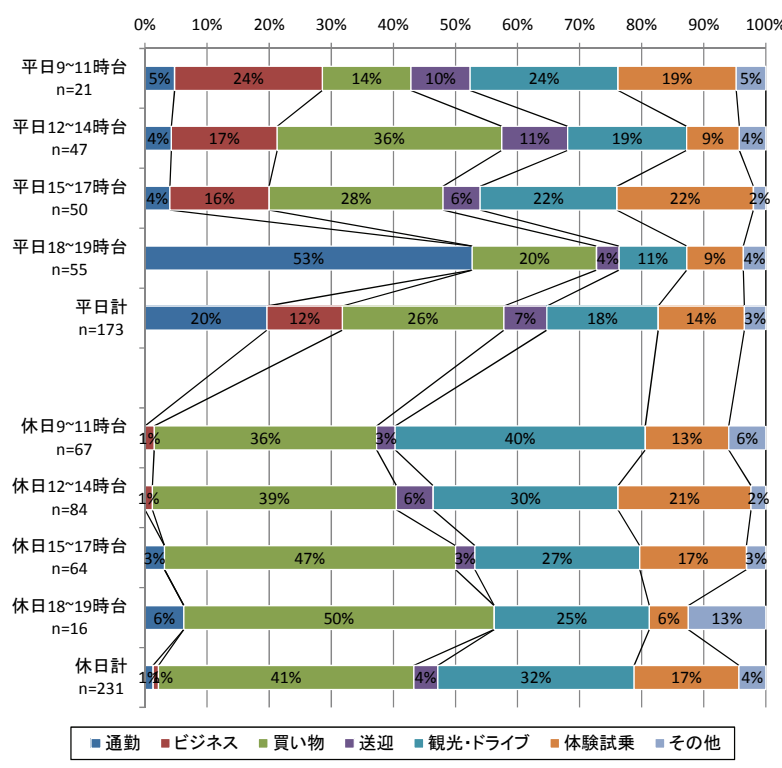

図-15 貸出時間帯別の利用目的
近に立地する桜木駐車場の利用が最も多いこと, 駅周辺 のステーションや大型商業施設の利用が多いこと, 具体 的な設置希望を示した回答者は少数であったが，その中 では駅から離れた大型商業施設や駅周辺を選択した回答 者が相対的に多かったことが明らかとなった. このこと から，商業業務施設が多く立地し，鉄道やバスが集中寸 る駅周辺や駅から少し離れた商業施設においてワンウェ イ型カーシェアリングの利用が多く見られたこと, 大宮 駅周辺に実証実験でもステーションを配置したが，実情 としては駅前広場に隣接した位置ではなく, 駅出口から 徒歩数分の位置に配置をしており, 中間web調査でも駅 からの近接性について改善の余地を指摘されていること から，より駅に近い位置での配置が望まれているものと 理解できる.

最後に，講習会時に行ったアンケート結果から，超小 型モビリティが普及した際の利用形態に関する意向につ いて図-17に示す. 将来超小型モビリティが普及した際 に利用を希望する形態としては，「カーシェアリング」 が最も多いことが明らかとなった。この理由としては,

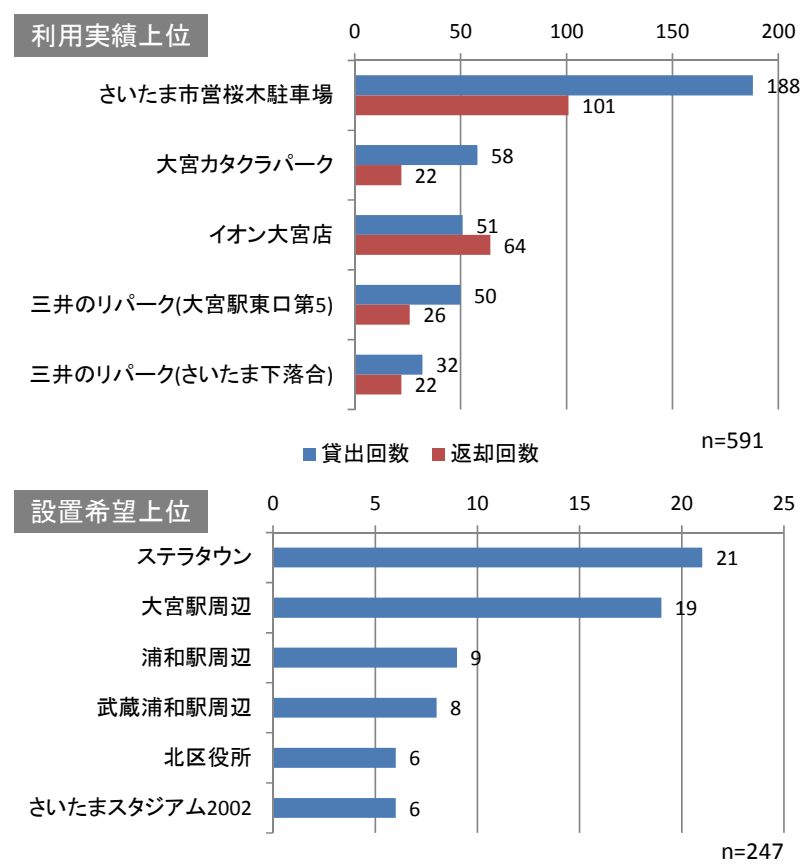

図-16 ステーション利用実績と設置希望意向

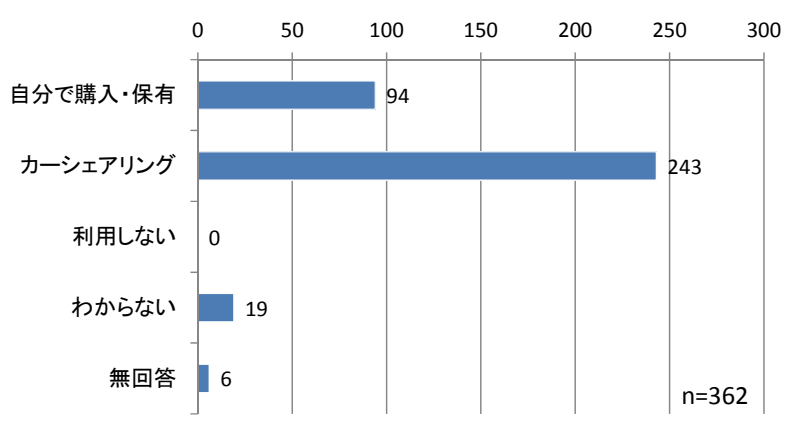

図-17 超小型モビリティ普及時の利用形態意向 
さいたま市周辺においては必ずしも自動車保有が1人1台 の水準とはなっておらず，家族と共用して1台を利用す るケースが多いと推察されること, 超小型モビリティの 車両特性上，すべての移動を1台で賄うことが難しいこ と，カーシェアリングであれば大きな支出をすることな く超小型モビリティを利用可能であること等が要因とな っているものと推察される.

\section{d）超小型モビリティの乗り物としての評価}

講習会の超小型モビリティ試乗後に実施したアンケー 卜結果から，ガソリンを使わない乗り物としての評価結 果を図-18に，車体の小さな乗り物としての観点からの 評価結果を図-19に示寸.

ガソリンを使わない乗り物の観点からのガソリン車と の比較では，交通不便地区と同様に，「環境に優しい」 に対し肯定的な評価をした人が9割を超え最も高い評価 を得た. 次に「音が静か」に対して肯定的な評価が高く なっている. 一方,「充電が心配」と思う人は7割を超

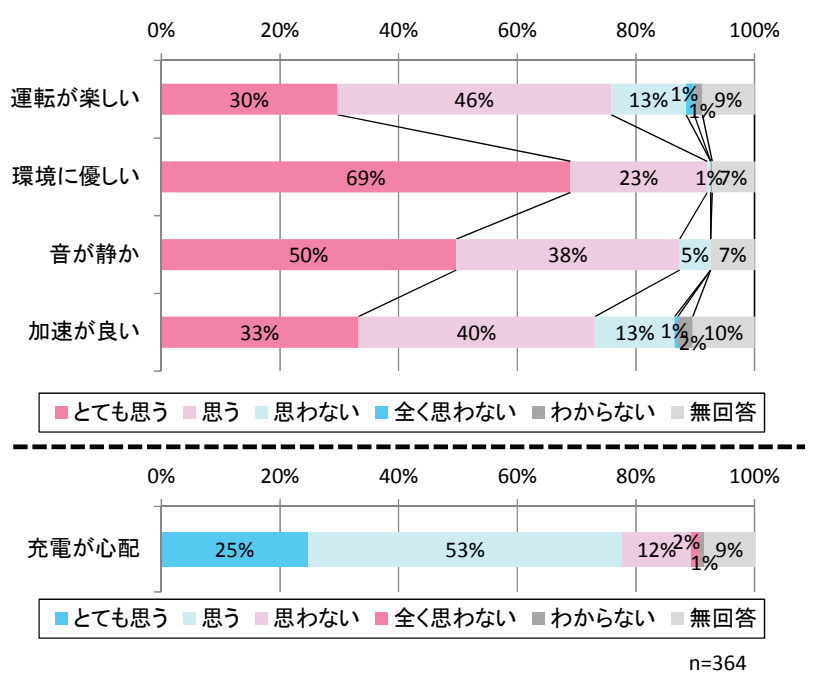

図-18 ガソリンを使わない乗り物としての評価 (都心部実証実験)

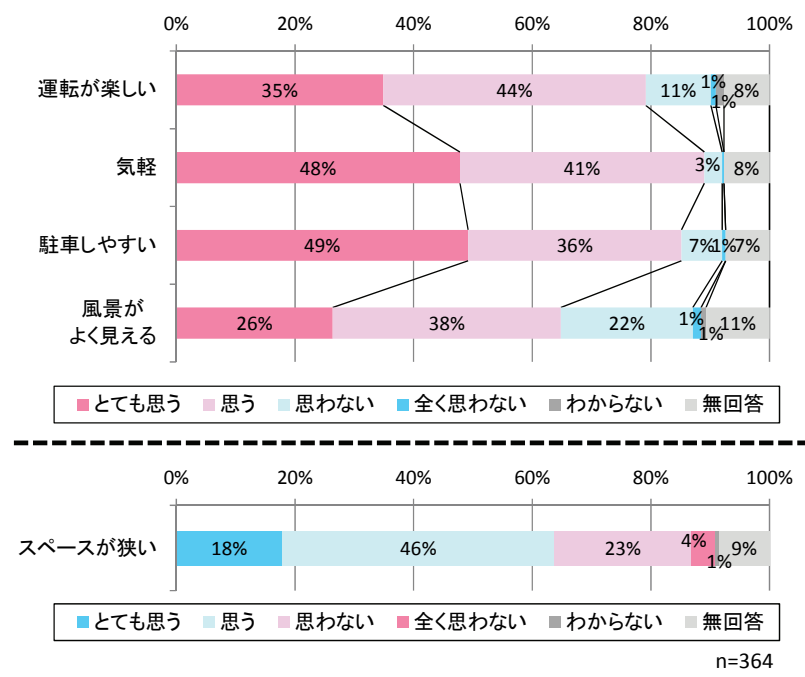

図-19 車体の小さい乗り物としての評価 (都心部実証実験)
えており, 不安要因となっている.このことから, 交通 不便地区と同様の評価を得ているものと理解できる.

また，車体の小さな乗り物の観点からのガソリン車と の比較では, 交通不便地区とは異なり,「気軽」に対し 肯定的な評価をした人が8割を超え最も高い評価を得た。 次に，交通不便地区で最も多かった「駐車しや寸い」，

「楽しい」の評価が高かった。「スペースが狭い」は6 割超の否定的な評価にとどまっている.つまり, 都心部 の実証実験では，車両そのものの取り回しのしやすさに 加え，ワンウェイ型カーシェアリングとして利用したい ポート間で利用できる条件も加味され, 超小型モビリテ イの持つ気軽さが評価されたと考える.

e） カーシェアリングのリピーター化モデル推定

講習会参加者375名中，実際にカーシェアリングを利 用したのは246名であり，そのうち102名(41\%)は2回以上 利用したリピーターであった。

実証実験結果を踏まえ, 将来的に継続的な利用が期待 されるのはどのような属性を有する利用者であるかを定 量的に分析することを目的として，カーシェアリング利 用者のリピーターモデルとして, 期間中のカーシェアリ ングの利用回数を被説明変数(1回のみ・2回以上)とする2 項ロジットモデルを推定した. 説明変数は, 個人属性と 講習会時のアンケートで尋ねた超小型モビリティについ ての評価であるため, 分析対象サンプルは, 利用者のう ち評価項目に関する設問を全て回答した190サンプル(そ のうちリピーター77名)とした.

推定結果を表-8に示す.この結果からは, 尤度比は大 きくモデルの適合性は高い，また，各パラメータの符号

表-8 カーシェアリングの利用者のリピーターモデル (都心部実証実験)

\begin{tabular}{|c|c|c|c|}
\hline \multicolumn{2}{|c|}{ 説明変数 } & 推定値 & t值 \\
\hline \multirow{5}{*}{$\begin{array}{l}\text { ガソリンを使わない } \\
\text { 乗り物としての評価 }\end{array}$} & 運転が楽しい & 0.13 & 0.41 \\
\hline & 環境に優しい & 0.81 & $1.83^{*}$ \\
\hline & 音が静か & 0.00 & -0.01 \\
\hline & 加速が良い & 0.15 & 0.58 \\
\hline & 充電が心配 & -0.30 & -1.19 \\
\hline \multirow{5}{*}{$\begin{array}{l}\text { 車体の小さい乗 り物 } \\
\text { としての評価 }\end{array}$} & 運転が楽しい & -0.93 & $-2.48^{\star *}$ \\
\hline & 気軽 & 0.11 & 0.30 \\
\hline & 駐車しやすい & -0.05 & -0.17 \\
\hline & 風景がよく見える & 0.41 & 1.57 \\
\hline & スペースが狭い & -0.07 & -0.32 \\
\hline \multicolumn{2}{|l|}{ 40歳以上ダミー } & -0.69 & $-1.99^{\star *}$ \\
\hline \multicolumn{2}{|l|}{ 男性ダミー } & 1.62 & $2.19^{\star \star}$ \\
\hline \multicolumn{2}{|l|}{ さいたま市民ダミー } & 0.63 & $1.73^{*}$ \\
\hline \multicolumn{2}{|l|}{ 体験試乗目的ダミー } & -1.21 & $-1.74^{*}$ \\
\hline \multicolumn{2}{|l|}{ 定数項 } & -4.12 & $-2.04^{* *}$ \\
\hline \multicolumn{2}{|l|}{ L(c) } & \multicolumn{2}{|c|}{-128.27} \\
\hline \multicolumn{2}{|l|}{$L(\theta)$} & \multicolumn{2}{|c|}{-112.33} \\
\hline \multicolumn{2}{|l|}{ 尤度比 } & \multicolumn{2}{|c|}{0.12} \\
\hline \multicolumn{2}{|l|}{ 尤度比検定 $\left(X^{\wedge} 2\right)$} & \multicolumn{2}{|c|}{$31.87^{* *}$} \\
\hline
\end{tabular}


条件も妥当である.

モデルからは，「環境に優しい」面を高く評価する人 はリピーターになりやすい一方で，「小さい車の運転が 楽しい」面を高く評価する人は，市販されていない超小 型モビリティの運転に興味があり，一度運転を体験する ことで一定の満足が得られるものと推察されることから 1 回のみの利用に留まる傾向が高いことが窥える。また, 属性別には, 40 歳未満, 男性, さいたま市民(居住地が 近い)を満たす層はリピーターになりやすいことが把握 された.

なお，カーシェアリングのサービス水準の検討におい ては「料金設定」や「利用可能車両数(利用したいとき に車両がある確率)」等の説明変数が有用であると考え られるが，今回の実証実験ではこれらの影響を把握でき ないため分析対象外としている.

\section{4. 大都市圏郊外部における超小型モビリティの 活用可能性}

前章では，大都市圈郊外部であるさいたま市における 超小型モビリティの利用実態と意向について分析を行っ た. 以下では, 得られた知見に基づき, 超小型モビリテ イの活用可能性に関する考察を行う。

\section{（1）交通空白・不便地区における活用可能性}

実証実験結果からは，車両特性に合致した短距離の移 動を中心に利用されたこと，高齢者の利用が多く見られ たこと, 超小型モビリティは駐車や走行の際に取り回し が楽であると回答した層が多く存在することが明らかと なった. このことから, 交通空白・不便地区においては, 高齢者を中心に，買い物や通院等の近距離移動において 超小型モビリティの活用可能性が存在すると考える.

また, 高齢化に伴って, 運転に対して抵抗を感じる場 面が増えると推察するが，超小型モビリティは取り回し が容易であるという評価を受けていることから，運転に 対する抵抗感を軽減させ, 外出機会の確保につながるこ とが期待できると考える.

一方で, 超小型モビリティの活用に向けては課題が存 在する. 本実証実験では鉄道やバスの端末交通手段とし ての利用は見られなかった. このため, 活用可能性の拡 大には, 駅やバス停付近における超小型モビリティ専用 駐車場所の確保や駐車料金優遇等の施策を展開，公共交 通機関との結節性向上を図ることで，自動車から公共交 通への転換を誘導することが必要であると考える.

また，現在保有する車両の代替での導入には抵抗感が あることから，活用可能性の拡大に向けては個人所有に 加え地域での共有方策の検討が必要であると考える.

\section{（2）都心部における活用可能性}

実証実験結果からは, 駅や大型商業施設を発着する都 心部内の移動を中心に利用されたこと, 利用者の多くは 30〜50歳代であったこと, 平日休日ともに多くの移動場 面で利用されたことが明らかになった．このことから， 都心部内での時間帯ごとに異なる移動目的に合致した形 で, 超小型モビリティを用いたワンウェイ型カーシェア リングが活用される可能性が存在すると考える.

また，将来超小型モビリティが普及した際の利用にあ たって, 車両の購入・保有ではなくカーシェアリングの 利用を想定する層が多い，これより，カーシェアリング には，車両保有に制約があり購入ができない層を取り込 むことが期待され，選択肢が購入のみの場合と比較して より多くの市民に活用される可能性が存在すると考える.

一方で, 今回の実証実験は車両数(9台), ステーショ ン数(34力所)ともに限定された条件下での実施となって おり, 車両数やステーション数の拡充, 駅周辺のステー ションにおける駅からの距離の短縮に対する改善要望や, 料金体系の改善要望等が寄せられた. このことから, 活 用可能性を高めるためにはサービス内容の更なる向上が 必要であると考える.

なお，実証実験においては多くの市民に超小型モビリ ティを用いたワンウェイ型カーシェアリングを体験して 頂くことが目的の一つであり，利用者の利便性向上を実 現するための各種措置を講じていることから，実証実験 において採算性を確保することはできていない，将来的 な運用に向けては, 今回の実績を踏まえ, 回送コストや 人件費等の費用削減方策，月額会員制度の導入などの収 入増加方策の導入に向けた具体的な検討が必要であると 考える.

\section{5. おわりに}

本研究では，さいたま市内の2地域における実証実験 結果を通じ, 大都市圈郊外部において超小型モビリティ の活用が期待されることを示した.

具体的には，高齢化の進展に伴い交通空白・不便地区 に居住する高齢者数はさらに増加すると予想されるが, これらの層の近距離移動の足として超小型モビリティが 活用される可能性を有すること, 都心部において超小型 モビリティを用いたワンウェイ型カーシェアリングを導 入することにより, 車両の購入には至らない層も含めて 幅広く活用される可能性を有することを明らかにした.

今後, 超小型モビリティの活用場面について引き続き 実証実験を行い, 活用可能性の追加的な検証を行うこと を予定している. 今回の実証実験では, 都心部において 一部公共交通からカーシェアへの転換が見られた.この ような利用は，公共交通の乗り継ぎが必要等，公共交通 
での移動への抵抗感が一因と推察され，この点も踏まえ， 超小型モビリティを総合交通体系の一翼として位置付け, 鉄道やバス，自転車等の交通手段とのバランスを考慮し ながら超小型モビリティの利用場面を想定すること，お よび，公共交通との結節性向上に向けて超小型モビリテ イの駐車場所や料金等の優遇施策を検討寸ることが望ま しいと考える.

謝辞 : 本研究の遂行にあたり，さいたま市小型電動モビ リティ利活用推進協議会の構成主体各位に多大なご協力 を賜った。ここに記して謝意を表する.

\section{参考文献}

1) 国土交通省：超小型モビリティの導入促進，＜http:// www.mlit.go.jp/common/000986236.pdf>, 2013.

2) 金利昭, 高崎祐哉：新しいコンパクト交通手段の特 性分析と共存性の問題, 土木計画学研究・論文集 D3 (土木計画学), Vol. 68, No. 5, pp. I 893-I_902, 2012.

3) 李昂, 安藤良輔, 西堀泰英, 加知範康, 加藤秀樹 : 立ち乗り型パーソナルモビリティの受容性に関する 研究, 土木計画学研究・論文集 D3 (土木計画学), Vol. 68, No. 5, pp. I_599-I_605, 2012.

4) 中村謙太, 溝上章志, 橋本淳也 : ワンウェイ型 $\mathrm{MEV}$ シェアリングシステムの導入可能性に関するシミュ
レーション分析, 土木計画学研究・講演集, Vol. 46, CD-ROM, 2012.

5) 須田義大，中野公彦，田中伸治，平沢隆之，牧野浩 志, 中川智皓, 平山遊喜 : パーソナルモビリティ・ ビークルの試作と環境・高齢社会への適応性に関す る基礎的検討, 生産研究, Vol. 63, No. 2, pp. 287-292, 東京大学生産技術研究所, 2011 .

6) 石橋伸介, 森田昌嗣, 曽我部春香: パーソナルモビ リティの価值構造に関する研究, 第 59 回研究発表大 会, 日本デザイン学会, 2012.

7) 溝上章志, 川島英敏, 大森久光, 永田千鶴, 野尻晋 一, 矢口忠博 : 高齢化社会においてパーソナルモビ リティが QOL に与える影響に関する実証調査, 土木 計画学研究・論文集 D3 (土木計画学), Vol. 68, No. 5, pp. I_141-I_153, 2012.

8) 落合淳太, 中川善夫, 松橋啓介, 谷口守 : 全国の市 区町村における太陽光発電による電力自給自足の潜 在的可能性, 土木計画学研究・論文集 D3 (土木計画 学), Vol. 69, No. 6, pp. II_217-II_225, 2013.

9) Vishwanath, A., Gan, H. S. and Kalyanaraman, S. : Personalised public transportation; A new mobility model for urban and suburban transportation, IBM Research Report, 2014.

10) さいたま市：コミュニティバス等導入ガイドライン, 2011.3.

(2016. 2. 26 受付)

\title{
A STUDY ON THE EFFECTIVENESS OF MICRO ELECTRIC VEHICLE IN THE METROPOLITAN SUBURBS
}

\author{
Daisuke SUNAGA, Sadayasu AONO, Hirokazu MATSUMOTO, \\ Yasuaki TERAMURA and Hisashi KUBOTA
}

The purpose of this study is to clarify the effectiveness of MEV in Saitama, the metropolitan suburbs based on the demonstration tests in 2014 .

Although the car depended areas are relatively less public transport coverage, aging population is just increasing in such areas, so they need to suffer from the difficulty of moving by themselves. In downtown, public facilities are widely spread, therefore, people should take a long walk from the central station to reach these facilities. Tackling these issues, we had two demonstration tests. The former was held at Kawai area in Iwatsuki-ward, where public transport is not convenient. In this test, people who took MEV class, could drive free two MEVs in the area. We found that older people tend to shop or go hospitals by MEV driving.

The second demonstration test was tried around Omiya Station, the central station in Saitama. We set 34 stations and put $9 \mathrm{MEVs}$ in this area, and operated one-way car sharing system. As a result, we found that high percentage of people tend to use MEVs within the central area in the weekend and weekdays. 